\author{
GABRIELAABRASOWICZ1 \\ Uniwersytet Ślaski w Katowicach \\ e-mail: abrasowicz.gabriela@gmail.com \\ MAGDALENA KOCH² \\ Uniwersytet im. Adama Mickiewicza w Poznaniu \\ e-mail: magdalena.jolanta.koch@gmail.com
}

\title{
Ofiary - wyobcowane - sprawczynie. Kobiecy punkt widzenia na przemoc i wojnę we współczesnym dramacie i teatrze (post)jugosłowiańskim
}

\author{
Abstract \\ Victims - Alienated - Agents. The Women's Point of View on Violence and War \\ in the Contemporary (Post)Yugoslav Drama and Theatre
}

The bloody conflicts accompanying the collapse of Yugoslavia in 1991-1995 have become one of the extremely interesting, recurrent subject in the (post)Yugoslav drama and theatre. The female artists and playwrights also leap at a chance to abreact the horrors of war. Their engaged art and writing defined by a syntagma: (anti)war female dramaturgy arises interest, because it is situated/placed in the opposition to the masculinist mode of describing armed conflicts, their side effects and consequences. The paper presents three categories of contemporary (post)Yugoslav female drama heroines who represent three role models in war narratives: Victims - Alienated - Agents. The analytical part of a paper consists of three parts. Firstly, the problem of female victims of ethnic rapes is presented on an example of drama Maria's Pictures (Slike Marijine, 1992) by Croatian playwright Lydia Scheuermann Hodak. Secondly, the category of alienated heroines is illustrated by a play Finger (Gishti, 2011) by Albanian author Doruntina Basha from Kosovo in which refugees problems and questions evoked by missing persons (husbands and sons) is thematised. Thirdly, there are presented three plays by Croatian author Ivana Sajko representing the figures of violence activism: a figure of avengeress (Archetype: Medea - monologue for a Women who Sometimes Speak, 2000), a female terrorist (Woman-Bomb, 2003) and an emperess-warrior (Europe - a monologue for Mother Courage

1 Praca powstała w wyniku realizacji projektu badawczego nr 2017/24/C/HS2/00436, finansowanego ze środków Narodowego Centrum Nauki.

2 Tekst powstał w ramach projektu badawczego numer 178029, Кьиженство, теорија и историја женске књижевности на српском језику до 1915. године, finansowanego przez Ministerstwo Oświaty, Nauki i Rozwoju Technologicznego Republiki Serbii. 
and her Children, 2004). The stress is also put on the artvivism as well as on catharctic function of this artistic creativity.

Keywords: (anti)war female dramaturgy, violence, artivism, (post)Yugoslav drama and theatre, gender studies

Słowa kluczowe: (anty)wojenne dramatopisarstwo kobiece, przemoc, artywizm, dramat i teatr (post)jugosłowiański, gender studies

Kryzys federacyjnej Jugosławii jako państwa wieloetnicznego narastał od lat osiemdziesiątych (po śmierci Josipa Broza-Tity), a dekadę później (1991-1995) zakończył się krwawą, brutalną wojną i był szokiem dla stabilnej, sytej, liberalnej Europy. Czterdzieści pięć lat po zakończeniu II wojny światowej, po doświadczeniach Zagłady, masowych przesiedleniach ludności, zmianach granic, transformacjach ustrojowych w Europie Środkowo-Wschodniej i Południowo-Wschodniej zaczęły powracać - zdawałoby się przebrzmiałe w tej części świata - takie pojęcia jak: ludobójstwo, czystki etniczne, przemoc, gwałty na skalę masową (nazwane później gwałtami etnicznymi), uciekinierzy i uchodźcy. Leksyka ta znów okazała się przydatna do opisu bieżącej sytuacji w Europie. Po niecałym półwieczu od zakończenia II wojny światowej popularny slogan „Nigdy więcej wojny!” stracił swoją wiarygodność i przestał być aktualny w południowo-wschodniej części kontynentu.

Wojna lat dziewięćdziesiątych XX wieku w Jugosławii z całą mocą pokazała swoje odrażające oblicze. Krwawe konflikty towarzyszące rozpadowi państwa federacyjnego w latach 1991-1995 urosły w związku z tym do rangi jednego z najbardziej traumatogennych, powracających i aktualizowanych tematów nie tylko w kręgach ludności cywilnej, lecz także wśród artystów i artystek. Czas wojny, a także lata powojenne postawily przed dramatopisarzami oraz dramatopisarkami wiele wyzwań. Mimo że upłynęły już dwadzieścia dwa lata od podpisania porozumienia w Dayton, dziewiętnaście lat od konfliktu w Kosowie zakończonego w 1999 roku bombardowaniem przez wojska NATO Serbii pod rządami Slobodana Miloševicia i dziesięć lat od uznania przez większość państw europejskich niezależnego Kosowa, temat wojny, uchodźstwa, przemocy nadal pojawia się w sztuce. Dramat jako tekst literacki, ale przede wszystkim teatr jako przestrzeń jego publicznej emanacji, czerpiący szeroko z tekstowej partytury, przemienił się w krajach byłej Jugosławii w swoistą arenę zbiorowej i indywidualnej terapii. Stał się dla wielu artystów zwierciadłem społecznych problemów, medium dla sumień, instrumentem pamięci, obszarem odpowiedzialności, także moralnej³ Rola dramatu i teatru (post)jugosłowiańskiego ${ }^{4}$ oraz jego uczestnictwo w procesie

3 Pisała o tym Sanja Nikčević. Por. S. Nikčević, Kako prikazati ljudske rane na sceni. Ratne teme u hrvatskoj, bosanskoj i angloameričkoj drami, Zagreb 2016.

${ }^{4}$ Zdecydowałyśmy się na zapis: (post)jugosłowiański, świadomie pozostawiając ,,post” w nawiasie, gdyż chodzi nam o podwójne odwołanie i do dramatu z okresu wojny (jeszcze jugosłowiańskiego), i do powstałego po rozpadzie państwa (już postjugosłowiańskiego). 
przepracowywania traumy wojennej - zwłaszcza w dyskursie nieorkiestrowanym oficjalnie czy państwowo - jest nie do przecenienia na badanym przez nas terenie.

Od początku wojny można zaobserwować kilka zjawisk, które znajdą potem odzwierciedlenie w dramacie. Po pierwsze, dramat i teatr stały się bardzo ważnym medium w profilowaniu nie tylko dyskursu na temat wojny i przemocy, lecz także współczesnego sposobu myślenia o roli sztuki w życiu społecznym, a w szczególności sztuki zaangażowanej. W tym kontekście wyraźny jest udział dramatu i teatru w kształtowaniu artywizmus. Wydaje się to nawet zrozumiałe w kontekście stosowania psychodramy oraz terapii poprzez teatr jako metod operacyjnych w pokonywaniu traum. Po drugie, po 1991 roku w rozpadającej się Jugosławii możemy zaobserwować po raz pierwszy w historii miejscowych kultur niespotykaną dotychczas na taką skalę aktywizację dramatopisarek. Mamy nawet do czynienia ze swoistą hiperprodukcją tekstową ze strony autorek. Obserwujemy ich obecność zarówno ilościową, jak i - co szczególnie warto podkreślić - jakościową ${ }^{6}$ Znacząco wzbogaca to perspektywę (po)wojennego dramatu i ma daleko idące konsekwencje artystyczne oraz społeczno-kulturowe. Dramatopisarki stały się współuczestniczkami rozwoju „nowego dramatu serbskiego/ chorwackiego"7 - zarówno jeśli chodzi o innowacyjność formy, jak i odwagę w podejmowaniu tematów. Obserwujemy zwrot ku kobiecej cielesności, a wojna i przemoc (wraz z ich konsekwencjami) stają się nośnym wątkiem, który pojawia się u nich w wielu różnorodnych wariantach i odsłonach. Po trzecie, konsekwencją tego widocznego i wyraźnego rozszerzenia ram genderowych w obrębie dramatu w krajach postjugosłowiańskich jest uwrażliwienie na problemy płci, także w kontekście tematów związanych z wojną. Powstało stosunkowo nowe zjawisko, które można określić syntagmą „kobiece dramatopisarstwo (anty)wojenne” (žensko dramsko (anti)ratno pismo) ${ }^{8}$. Budzi ono coraz większe zainteresowanie, gdyż sytuuje się często w kontrze do dominującego maskulinistycznego trybu opisywania konfliktów zbrojnych (jak np. „maczyzm”, typ ,jugomężczyzny”, idealizowany heroiczny obraz walki w obronie narodu). Dramatopisarki - jak

5 Artywist(k)a [artyst(k)a + aktywist(k)a] wykorzystuje swoją zaangażowaną społecznie twórczość w walce z niesprawiedliwością i uciskiem. Por. Y. Goris, S. Hollander, Activism, Artivism and Beyond. Inspiring initiatives of civic power, Partos 2017, https://www.partos.nl/fileadmin/files/ Documents/Activism_Artivism_and_Beyond.pdf(dostęp: 8.01.2018).

6 Szczegółowo pisała o tym Gabriela Abrasowicz. Por. G. Abrasowicz, Dramat ciała, ciało w dramacie. Twórczość serbskich i chorwackich dramatopisarek w latach 1990-2010, Wrocław 2016.

Ibid., s. 66-88.

8 Określenia dramatopisarstwo kobiece (žensko dramsko pismo) powstało przez analogię do terminu žensko pismo, które jest thumaczeniem écriture féminine; używali go w swoich analizach produkcji dramatopisarskiej chorwaccy badacze: Lada Čale Feldman, Postoji li suvremeno hrvatsko dramsko žensko pismo?, „Republika” 1996, br. 3-4, s. 29-40, i Leo Rafolt, Uvod [w:] Odbrojavanje: antologija suvremene hrvatske drame, ur. L. Rafolt, Zagreb 2007, s. 7-27. Termin (anti)ratno pismo(anty)wojenny dyskurs literacki - włączył do swoich rozważań sarajewski badacz Enver Kazaz. Por. E. Kazaz, Krvavi lom društva i poetički prevrati romana, „Sarajevske Sveske” 2006, br. 13; idem, Prizori uhodanog užasa, „Sarajevske Sveske” 2004, br. 5. Pojęcia te funkcjonują również w innych krajach regionu. Bardziej operatywna i adekwatna wydaje się jednak w kontekście niniejszych rozważań kontaminacja „kobiece dramatopisarstwo (anty)wojenne” (žensko dramsko (anti)ratno pismo), stworzona specjalnie na potrzeby tej pracy. 
wynika z naszej lektury - stają się szczególnie wyczulone na wojenne historie kobiet (przemoc, gwałty etniczne, problem wstydu, wycofania, niemej pozycji kobiet w konflikcie), czyli starają się pokazać ich perspektywę i artykułować te problemy. Jednym słowem, teksty kobiecego autorstwa ${ }^{9}$ to dziś niezwykle istotny pas transmisyjny marginalizowanego dotąd doświadczenia wojennego, stający się przy tym strategią oporu wobec dotychczasowych opisów heroicznej postawy męskich bohaterów. Artystki egzekwują prawo kobiet do własnej opowieści i wersji wydarzeń. Często dochodzą w ich twórczości do głosu historie, które odbiegają od oficjalnych dyskursów władzy.

W niniejszym tekście interesuje nas właśnie perspektywa płci w doświadczaniu wojny. Produkcja dramatopisarska reprezentująca „kobiece spojrzenie na męskie sprawy" 10 jest dość obfita, choć długo nie była dostrzegana ani odnotowywana. Utwory te stosunkowo rzadko pojawiały się w antologiach lub na afiszach teatrów repertuarowych. Wzmożenie recepcji (unowocześniony tryb promocyjno-dystrybucyjny ${ }^{11}$, przekłady na języki obce, mobilność kulturowa) i zmiany świadomościowe spowodowały, że (anty)wojenne dramatopisarstwo kobiece stało się szerzej znane i zyskuje uznanie. Spośród pięćdziesięciu powstałych dotąd tekstów krążących wokół tematu wojny zdecydowaną większość stanowią sztuki napisane przez autorki z Chorwacji, Serbii oraz Bośni i Hercegowiny. Reakcje słoweńskich i macedońskich dramatopisarek były nie tak intensywne ze względu na słabiej tam odczuwane konsekwencje konfliktu. Ilościowo skromniej reprezentowana jest kobieca produkcja dramatopisarska w Czarnogórze i Kosowie, ponieważ o ich odrębności państwowej i artystycznej można mówić dopiero od 2006 (w przypadku Czarnogóry) i 2008 roku (w przypadku Kosowa). Niemniej jednak z mnogości (post)jugosłowiańskich dramatów tematyzujących wojnę i przemoc udało nam się wyodrębnić trzy główne kategorie bohaterek, odgrywających modelowe role w historiach/narracjach o przemocy wojennej: ofiar -

9 Syntagma „kobiece autorstwo“ wypracowana przez krytykę feministyczną funkcjonuje jako termin w literaturze przedmiotu zarówno w krajach byłej Jugosławii, jak też w Polsce - i do niego się tu odwołujemy.

10 Tytuł wystąpienia i analitycznego artykułu chorwackiego teatrologa Darka Lukicia. Por. D. Lukić, Ženski pogled na mušku stvar. Ratna tematika u suvremenih hrvatskih dramatičarki s jednom muškom iznimkom [w:] Govor drame. Govor glume. Zbornik radova sa simpozijuma „Dramski tekst danas u Bosni i Hercegovini, Hrvatskoj i Srbiji i Crnoj Gori”, ur. S. Anđelković, B. Senker, Zagreb 2007, s. 135-155.

11 Oprócz wciąż sporadycznych publikacji w antologiach (w Chorwacji: Nova hrvatska drama: izbor iz drame devedesetih, ur. J. Boko, Zagreb 2002; Odbrojavanje: antologija suvremene hrvatske drame, red. L. Rafolt, Zagreb 2007; Antologija hrvatske ratne drame (1991-1995), red. S. Nikčević, Zagreb 2011; Antologija hrvatske ratne komedije 1991-1997, red. S. Nikčević, Zagreb 2013; w Serbii: Predsmrtna mladost: antologija najnovije srpske drame (1995-2005), red. V. Jezerkić, S. Jovanov, Beograd 2006; Istorija i iluzija: antologija najnovije srpske drame (1995-2005), red. V. Jezerkić, S. Jovanov, Beograd 2007; Radnici umiru pevajući. Drame, red. M. Stefanović, T. Kaliterna, Beograd 2011; Prst. Zbirka savremene drame, red. V. Bošković, Beograd 2012; Biseri iz upravničkih fioka, red. S. Bodroža, Beograd 2013) teksty dramatopisarek są też dostępne w formie elektronicznej (archiwum internetowe drame.hr, nova-drama). Realizowane też były na coraz większą skalę czytania performatywne (na zasadzie autopromocji, w wykonaniu własnym lub ze wsparciem aktorów) oraz spektakle w teatrach niepublicznych i instytucjach nieteatralnych (domy kultury, świetlice). 
wyobcowanych - sprawczyń. Z tych trzech modeli pierwszy i drugi wydają się najbardziej oczywiste i najłatwiejsze do rozpoznania, trzeci jest mniej ewidentny - choć i na ten temat powstało kilka ważnych dramatów. Te modele przybliżymy na najbardziej reprezentatywnych przykładach. Zanim to nastąpi, chcemy podkreślić, że z większości prezentowanych tekstów wyłania się feministyczny profil dramatów pisanych przez kobiety. Dramatopisarki stają się swoistymi literackimi i kulturowymi rzeczniczkami problemów związanych z wojną i skutkami etnonacjonalizmu, dramat zaś bywa narzędziem odważnej diagnozy społeczno-politycznej, a nawet interwencji terapeutycznej. Zaangażowanie autorek dotyczy zwłaszcza zjawiska gwałtów etnicznych. Kobiety ofiary nie chcą o tym mówić z wielu względów - boją się stygmatyzacji środowiskowej oraz pogłębienia traumy. Milczenie ofiar staje się sposobem zachowania twarzy w społeczeństwie patriarchalnym (zwłaszcza w kontekście odradzającego się w kilku krajach postjugosłowiańskich islamu). Dramatopisarki pełnią zatem swoistą funkcję ratowniczą dla opowiadanych historii wojennych, a w konsekwencji też terapeutyczną dla niemej pozycji indywidualnych ofiar. Mówią w ich imieniu, przepracowują ich konkretne mikrohistorie, tworząc modele uniwersalizujące (będzie o tym jeszcze mowa później). Należy podkreślić, że wektor konstrukcyjny wielu dramatów przebiega na linii: wydarzenie - opowieść - dramat - przedstawienie lub innymi słowy: dokumentalizm - oralność - tekstualność - performatywność.

\section{Ofiary}

Wydarzenia wojenne z lat dziewięćdziesiątych ubiegłego wieku wyostrzyły artystyczne oko i ucho na różne rodzaje agresji w stosunku do kobiet. W tekstach dramatów do głosu dochodzą negatywne doświadczenia seksualne ofiar, akty szturmowania granic kobiecego ciała oraz działania zagrażające ich życiu i/lub zdrowiu. W utworach (post)jugosłowiańskich dramatopisarek pojawiły się różne odsłony przemocy, a w wielu przypadkach stanowiły zasadniczą oś tematyczną dramatu. Ujawnienie niewygodnych faktów historycznych i bezpośredni dostęp do relacji ofiar umożliwiły autorkom dokonanie pewnej tekstowej lub performatywnej rekonstrukcji zdarzeń oraz opisanie specyficznej taktyki zdominowania ciała „Innej”, traktowanej jako wróg etniczny.

Symptomatyczne dla konfliktów zbrojnych zjawisko metodycznych gwałtów, którym towarzyszą katowanie i intencjonalne, systemowe zapładnianie, zostało, jeszcze przed rezolucją Rady Bezpieczeństwa ONZ ${ }^{12}$ z 2008 roku, nagłośnione przede wszystkim dzięki reportażom dziennikarskim, raportom Specjalnego Sprawozdawcy ONZ ds. przestrzegania praw człowieka Tadeusza Mazowieckiego oraz takim publikacjom jak: Mass Rape: The War against Women in Bosnia-

12 Rezolucja nr 1820 przyjęta przez Radę Bezpieczeństwa podczas 5916 spotkania, 19.06.2008, UN Doc. S/RES/1820 (2008). Podkreślała ona niszczycielski charakter przemocy wobec kobiet, która w określonych okolicznościach może konstytuować zbrodnie wojenne, zbrodnie przeciw ludzkości, a nawet zbrodnię ludobójstwa. 
-Herzegovina ${ }^{13}$ i Rape Warfare. The Hidden Genocide in Bosnia-Herzegovina and Croatia $^{14}$. Również działania Międzynarodowego Trybunału Karnego ds. Zbrodni Wojennych w byłej Jugosławii w Hadze i postępujące rozluźnienie paktu milczenia łączącego niegdyś ofiary $i$ ich winowajców, który jednak wciąż nie został do końca złamany, oraz problem przemocy seksualnej wobec kobiet mającej miejsce w okresie rozpadu państwa stały się przedmiotem opracowań artystycznych dramatopisarek z Bośni i Hercegowiny (Jasna Šamić ${ }^{15}$, Elma Tataragić ${ }^{16}$, Nermina Kurspahić $^{17}$ ), Serbii (Mirjana Ojdanic ${ }^{18}$ ) oraz Chorwacji (Nataša Antulov $\left.{ }^{19}\right)^{20}$.

Na tym tle wyróżnia się utwór o przełomowym znaczeniu, który w całości został oparty na faktach. Chodzi o monodram Obrazy Marii (Slike Marijine ${ }^{21}$ ) autorstwa Lydii Scheuermann Hodak (ur. 1942), napisany już w 1992 roku, lecz opublikowany dopiero w roku 1996. W tej próbie odnalezienia właściwej reprezentacji dla wojennej traumy nadużycia względem kobiet zostały odzwierciedlone z zastosowaniem zupełnie innych, nieznanych wcześniej środków. Dramat został uznany za prawdziwy fenomen, ponieważ w odczuciu odbiorców chorwacka autorka nie napisała go dla rozgłosu, ale z potrzeby interwencji i zniwelowania poczucia bezsilności ${ }^{22}$. Tekst powstał na podstawie autentycznej historii, którą Scheuermann Hodak usłyszała od pewnej staruszki pracującej w czasie wojny w slawońskiej wsi jako akuszerka. Dramatopisarka nawiązała nawet współpracę z chorwackim oddziałem Caritas i próbowała dowiedzieć się, jak potoczyły się losy tamtejszych kobiet, późniejszych bohaterek jej sztuki.

Chorwacka autorka opisuje losy prawie pięćdziesięcioletniej nauczycielki, która wraz z córką doświadcza napaści seksualnej w okupowanej wsi, wskutek czego obie zachodzą w ciążę. Ciało Marii odrzuca płód, a jej jedynaczka w milczeniu rodzi dziecko i zaraz po tym umiera. Dojrzała kobieta traci córkę, ale staje przed nową rolą, tym razem babci. Wnuczka - owoc gwałtu etnicznego - traktowana jest jak bolesne memento, dlatego jej obecność nie może być od razu zaakceptowana. Krzywda łącząca trzy kobiety: babcię, córkę i wnuczkę, stanowi element konsekwentnie realizowanego planu wszczepiania obcego elementu,

13 Mass Rape: The War against Women in Bosnia-Herzegovina, ed. A. Stiglmayer, Lincoln 1994.

14 B. Allen, Rape Warfare. The Hidden Genocide in Bosnia-Herzegovina and Croatia, Minneapolis 1996.

15 J. Šamić, Spotkanie (Susret, 1998), Widmo (Sablast, 2000).

16 E. Tataragić, Fatum albo Ewa czeka (Kob ili Eva čeka, 2000).

17 N. Kurspahić, Kwaśne deszcze (Kisele kiše, 2005).

8 M. Ojdanić, Ślad ludzkich zębów (Trag ljudskih zuba, 2001).

19 N. Antulov, Siedziałem i stuchałem, jak je (Sjedio sam i slušao je kako jede, 2013). Ten duodramat przekształcił się w 2015 roku w bardziej złożony projekt zatytułowany Sh. Sh.

20 Temat gwałtu wojennego pojawił się w realizacjach artystycznych chorwackiej pisarki i eseistki Slavenki Drakulić: Oni nie skrzywdziliby nawet muchy (Oni ne bi ni mrava zgazili, 2003, zwłaszcza rozdz. Chłopcy się tylko zabawili), Jakby mnie nie było (Kao da me nema, 1999; ekranizacja As If I Am Not There, reż. J. Wilson, 2012), wnuczki marszałka Tito Svetlany Broz: Dobrzy ludzie w czasach zła (Dobri ljudi u vremenu zla, 1999) oraz bośniackiej reżyserki filmowej Jasmili Žbanić w filmie Grbavica nagrodzonym Złotym Niedźwiedziem na festiwalu filmowym w Berlinie (2006).

21 L. Scheuermann Hodak, Slike Marijine [w:] Žene, ljubav i ratovi, Osijek 2009.

22 S. Nikčević, Lydia Scheuermann Hodak ili dramski pisac izvan trendova [w:] L. Scheuermann Hodak, Žene, ljubav i ratovi, Osijek 2009, s. 7-8. 
w postaci dziecka wroga etnicznego ${ }^{23}$. Tytułowa Marija, dzięki terapii poprzez sztukę, rekonstruuje obrazy z przeszłości: sceny gwałtu, rany na ciele córki, etapy ucieczki i tułaczki, potwierdzenie ciąży, śmierć córki po porodzie, ale też oczyszczający dla niej moment własnego poronienia. Malowanie obrazów (głównie symboliczną czerwoną farbą) połączone zostaje ze swoistą spowiedzią monologiem, a najbardziej przykre wspomnienia wyłaniają się z otchłani i stopniowo się klarują. Działanie bohaterki jest jednak nieświadomie kierowane do odbiorców, bo nie realizuje się wyłącznie jako wewnętrzna wypowiedź między dwoma ja (dawniej i teraz) ${ }^{24}$. W jej wyznaniu zawarty jest fragment kolektywnej tragedii kobiet, która trwa również po wojnie. Stłumić może ją tylko udzielone przebaczenie i przyjęcie wnuczki. Po konfrontacji ze śmiercią córki podczas porodu dziecka, które ,przyszło na ten świat jako zemsta i kara” ${ }^{25}$, Marija ostatecznie przepracowuje traumę $i$ akceptuje życie powstałe w wyniku wojny ${ }^{26}$. Autorka sfinalizowała dramat, opierając się w dużej mierze na formule myślenia życzeniowego, aprobaty istoty ludzkiej powstałej w wyniku gwałtu, i ukazała odbiorcom kobietę, która nawet z przytłaczającym bagażem tragicznych doświadczeń potrafi odnaleźć „klucz do przeżycia"27 $\mathrm{i}$ iść dalej.

Obrazy Marii to utwór długo niedoceniany na rodzimym gruncie. Ze względu na transpozycję uniwersalnych, humanistycznych wartości oraz potencjał terapeutyczny doczekał się jednak szerokiej międzynarodowej recepcji oraz licznych przetworzeń i premier, m.in. w Niemczech, Iranie, Luksemburgu, Argentynie, USA, Egipcie, Syrii ${ }^{28}$.

${ }^{23}$ V. Nahoum-Grappe, Gwalt jako broń wojenna, thum. K. Bartkiewicz [w:] Czarna księga kobiet, red. C. Ockrent, S. Treiner, tłum. K. Bartkiewicz i in., Warszawa 2007, s. 51.

24 A. Zlatar, Tekst, tijelo, trauma: ogledi o suvremenoj ženskoj književnosti, Zagreb 2004, s. 195.

25 L. Scheuermann Hodak, Slike..., s. 27.

26 J. Poljak-Rehlicki, Ključ za preživljavanje: ženska ratna trauma u monodrami „, Slike Marijine” [w:] Size zero/mala mjera 2. Ženski lik u književnom tekstu, ur. A. Nikčević-Batrićević, Podgorica 2011, s. 97.

27 H. Sablić-Tomić, Gola u snu. O ženskom književnom identitetu, Zagreb 2005, s. 160.

28 Maria Without Name, Theatre Moasar (Iran 2002); Maria's Pictures, spektak1 amatorski w Marienthalu (Niemcy 2001); Marijas Bilder, $2^{\text {nd }}$ European Festival of Theatre Creation „Act in” (Luksemburg 2003); Los cuadros de Marija, MxM Teatro del Instituto Nacional de Teatro Cordoba (Argentina 2004); Slike Marijine, HNK Osijek (Chorwacja 2004); spektakl w języku arabskim, Al Arabi Theatre Group (Kuwejt 2005); Maria's Pictures, Theatre Rhode Island College (USA 2006); Maria's Pictures, Upstream Theatre, St. Louis (USA 2006); Slike Marijine, Mostar (Bośnia i Hercegowina 2007); spektakl multimedialny w Kairze (Egipt 2007); spektakl w języku arabskim w Damaszku (Syria 2008). 


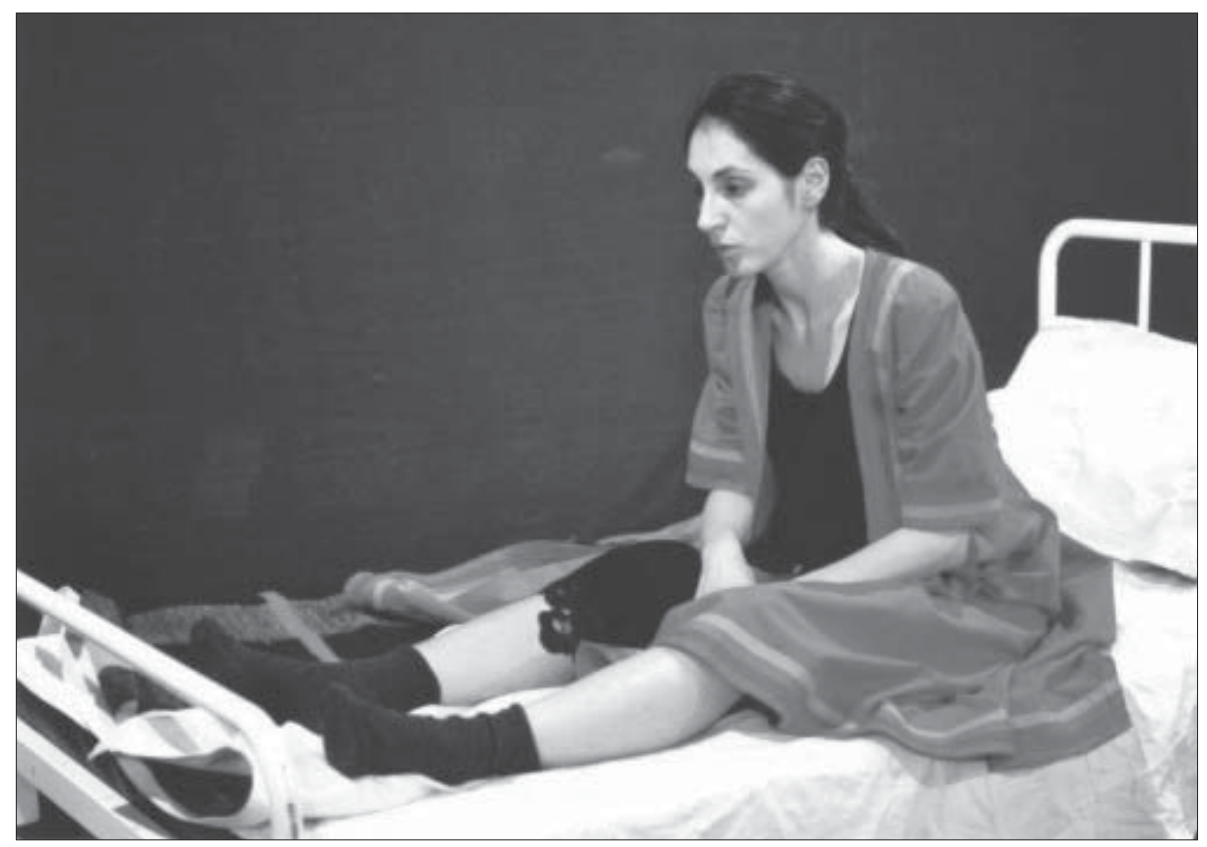

Fot. 1. L. Scheuermann Hodak, Slike Marijine, reż. S. Špišić, HNK Osijek, 2004.

\section{Wyobcowane}

W ostatnich latach wskazuje się na potrzebę transpozycji obrazów wojny, nie tylko bazujących na oczywistych zbrodniach przeciw życiu i zdrowiu aktywnych uczestników konfliktów, lecz także na codziennych doświadczeniach ludności cywilnej. Szczególnie ważne jest nowe spojrzenie na kobiece przeżycia, które powinny być przedstawiane w intersekcjonalnym ujęciu ${ }^{29}$. Pozycjonuje ono osobiste tragiczne przeżycia kobiet w odniesieniu do szerszych ram i struktur społecznych, politycznych, ekonomicznych czy religijnych. Przedstawione w dramatach kobiety funkcjonują często jako ofiary nakładających się na siebie dwóch reżimów: zewnętrznego (realiów życia w czasie wojny i po wojnie, zmagania się z utratą bliskich, mienia, pracy, domu, z koszmarem przymusowej emigracji i osadzenia w obozach dla uchodźców) i wewnętrznego (konieczności podporządkowania się patriarchalnej strukturze społecznej). Ich egzystencja, w którą wkracza żywioł historii i polityki, polega na wykluczeniach, a ich nowy świat powstaje na fundamencie niewidzialności. Czują się one wyobcowane we własnym lub nowym otoczeniu.

29 N. Shalhoub-Kevorkian, Liberating Voices: The Political Implications of Palestinian Mothers Narrating Their Loss, „Women Studies International Forum” 2003, Vol. 26, Issue 5, s. 391-392. 
Autorki takie jak Jasna Šamić ${ }^{30}$ z Bośni i Hercegowiny, Biljana Srbljanović ${ }^{31}$ z Serbii i Tena Štivičić ${ }^{32}$ oraz Lydia Scheuermann Hodak $^{33}$ z Chorwacji zareagowały na wydarzenia związane z exodusem ludności w czasie wojen w Bośni i Hercegowinie oraz Kosowie, ale też na późniejszą antyuchodźczą panikę, powstałą w reakcji na falę przesiedleńców z innych obszarów geokulturowych. Zwróciły one uwagę na fakt potwierdzający wyniki badań socjolożki izraelskiego pochodzenia Niry Yuval-Davis, że uchodźstwo jest praktyką silnie związaną z płcią społeczno-kulturową, ponieważ większość osób ${ }^{34}$ zmuszonych do opuszczenia swojego kraju stanowią kobiety i dzieci. U wspomnianych dramatopisarek pojawia się zatem typ bohaterki doświadczającej zwielokrotnionego wyobcowania, zmagającej się z problemami ucisku i dyskryminacji w obozach dla uchodźców. Tego typu bohaterkom równie mocno doskwierają powszednie problemy wynikające z nieznajomości języków obcych, skandalicznych warunków sanitarnych, ograniczenia swobody poruszania się i samostanowienia o sobie.

Na szczególnego rodzaju gettoizację, a nawet systemowe wykluczenie skazane są przede wszystkim kobiety, których bliscy, zwłaszcza mężowie lub synowie, mają niejasny status osoby zaginionej. W sytuacji, gdy - nawet po kilkunastu latach nieobecności męża - istnieje uzasadnione podejrzenie, że ten nie żyje, lecz jego ciało nie zostało odnalezione, kobieta ma prawny status żony, a nie wdowy ${ }^{35}$. Ten trudny temat społecznych skutków wojny oglądany z kobiecej perspektywy oraz ich społecznego wykluczenia, zwłaszcza matek, żon, córek i sióstr, a także przez pryzmat procesu poszukiwań osób zaginionych podczas działań zbrojnych w Bośni i Hercegowinie oraz Kosowie, podejmują właśnie dramatopisarki. Problem tylko w niewielkim stopniu sprowadza się do identyfikacji ekshumowanych szczątków, zapoznania się z wynikami analiz laboratoryjnych przeprowadzanych na przykład przez Międzynarodową Organizację ds. Osób Zaginionych. Bardzo często kobiety, zmuszone przez układ społeczny do biernego oczekiwania na powrót zaginionych lub jakąkolwiek informację o nich, czują się osamotnione i wyobcowane, a w akcie desperacji narażają się na to, że padną ofiarą oszustw i wyłudzeń ze strony osób, które chcą im sprzedać informacje o ich nieobecnych bliskich. Ponieważ zwłaszcza w literaturze kosowskiej odnotować można dotkliwy brak opisów (po)wojennej rzeczywistości z perspektywy kobiet, dlatego duodramat Doruntiny Bashy (ur. 1983) stanowi niezwykle ciekawą i potrzebną propozycję artystyczną na temat wykluczonej społecznie bohaterki.

30 J. Šamić, Wspomnienie o życiu (Sjećanje na život, 1995), All on board (2004).

31 B. Srbljanović, Belgradzka trylogia (Beogradska trilogija, 1997), Supermarket (2001), Ameryka, część druga (Amerika, drugi deo, 2013).

32 T. Štivičić, Ostrożnie! Szkto! (Fragile!, 2007), Niewidzialni (Nevidljivi, 2016).

33 L. Scheuermann Hodak, Drzewo akacjowe (Bagremovo drvo, 2012).

34 Badaczka szacuje wielkość tej grupy na $80 \%$ populacji. Por. N. Yuval-Davis, Nacionalistički projekti i rodni odnosi, „Treća” 2003, br. 1-2 (V), s. 208-233.

35 O tym problemie szczegółowo pisał w swoim eseju Damir Arsenijević. Por. D. Arsenijević, Odrodzić płeć kości: polityka pamięci w Bośni i Hercegowinie, tłum. M. Koch, K. Taczyńska, „Teksty Drugie" 2017, nr 2, s. 301-317. 
Sztuka Palec $\left(\right.$ Gishti $\left.^{36}, 2011\right)$ prisztińskiej autorki to tragiczna opowieść o trudnej relacji teściowej i synowej, które są zmuszone do egzystencji obok siebie w oczekiwaniu na powrót najważniejszego dla nich mężczyzny (jednocześnie syna i męża). Zaginął on, podobnie jak pięć tysięcy osób ${ }^{37}$, podczas konfliktu w Kosowie. Nieobecność żywiciela rodziny i jego symboliczne zawieszenie między światem żywych i umarłych istotnie wpływa na tryb codziennego funkcjonowania kobiet pod względem ekonomicznym i emocjonalnym, a oprócz tego znacząco nasila blokady wynikające z życia w albańskim patriarchalnym systemie regulowanym kodeksem Leki Dukagjiniego, określanym jako „Kanun”. Tytułowy palec wymierzony jest w zjawisko wyobcowania i stygmatyzacji oraz narzuconej przez obyczaj izolacji, która tylko wzmaga bezbronność, osamotnienie i unieruchomienie kobiet ograniczanych społecznym zakazem podjęcia pracy, samodzielnego poruszania się, uwolnienia własnej niezależności.

Sztuka jest pokłosiem wcześniejszych projektów zatytułowanych Gtosy (Zërat) i Najdluższa zima (Dimri më i gjatë), które były realizowane także z udziałem Doruntiny Bashy i aktywnie wspierane przez Misję Tymczasowej Administracji Organizacji Narodów Zjednoczonych w Kosowie. Ta nowatorska inicjatywa dokumentalnego, humanitarnego teatru interaktywnego, który obnażał systemowe nadużycia w Kosowie, stanowiła przede wszystkim narzędzie pomocy i terapii dla mieszkańców. Pracownicy specjalistycznych organizacji oraz Centrum Rozwoju Teatru Dziecięcego jako realizatorzy tych dwóch zazębiających się przedsięwzięć zbadali i zrekonstruowali język rodzin ofiar konfliktu etnicznego. Dążyli do stworzenia sytuacji, w których można by włączyć do dyskursu o wojnie niewysłuchane dotąd głosy i tym samym aktywizować uczestników (częściej uczestniczki) i zachęcić ich do wyartykułowania swoich krzywd oraz potrzeb. Listy oraz rejestrowane wypowiedzi służyły często za punkt wyjścia dla tekstów dramatycznych i przygotowywanych mikrospektakli. Rezultaty pracy zostały zaprezentowane rodzinom zaginionych, aby poznać ich reakcje i uwagi oraz skłonić ich do dyskusji. Było to niezwykle skuteczne działanie w nurcie określanym „teatrem poza teatrem” lub „teatrem dla życia”. Przy okazji tych działań powstały zatem dramaty, które funkcjonują także w szerszym środowisku, poza Kosowem. Dramat Palec został wystawiony w języku serbskim na deskach teatru Bitef w Belgradzie (2012), a także w Sarajewskim Wojennym Teatrze SARTR (SArajevski Ratni TeataR, 2014). To dowód na to, że siła emisyjna tekstu kosowskiej autorki rozprzestrzeniła się na region postjugosłowiański.

36 D. Basha, Prst, prev. Q. Ondozi [w:] Zbirka savremene drame 2, red. V. Bošković, Beograd 2012.

37 Do 2006 roku za zaginionych w wyniku konfliktu kosowskiego uznano ponad 5000 osób: około 1800 kosowskich Albańczyków, około 500 kosowskich Serbów i członków grup mniejszościowych. Por. Nestala lica - pitanja i odgovori [w:] Zërat, Voices, Glasovi, red. J. Neziraj, A. Zadel, Pristina 2006. 


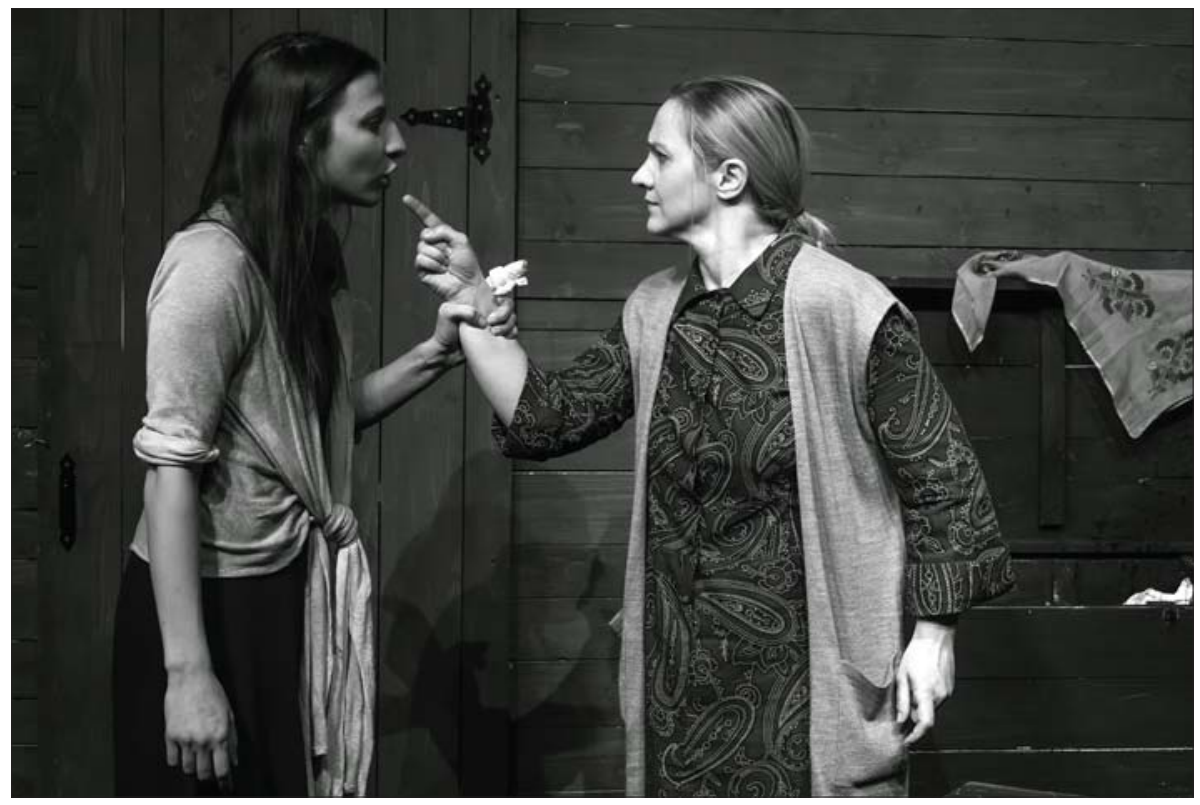

Fot. 2. D. Basha, Prst, reż. S. Begović-Ćorić, SARTR, Sarajevo 2014.

\section{Sprawczynie}

Dramatopisarki (post)jugosłowiańskie odniosły się również do faktu, że wojna, nawet jako typowo męska gra społeczna, nie oznacza braku możliwości inkluzji kobiet i ich zaangażowania po drugiej stronie barykady. Ten wariant twórczości usytuowany poza głównym nurtem powstał dzięki zastosowaniu strategii obalenia utartego schematu, który zakładał konfrontację męskiej przemocy i kobiecej niemocy lub męskiego aktywnego bohatera wojennego i zdobywcy (,jugo-mężczyzny") i biernej, eksploatowanej kobiety, ewentualnie opiekunki ogniska domowego. Korpus tekstów dramatycznych, których bohaterki odkryły w sobie moc sprawczą i posiadły władzę, nie jest obszerny, ale jego zasięg rośnie od lat dziewięćdziesiątych XX wieku. Od tego momentu kobiety z zauważalnym natężeniem przyjmowały role przełamujące stereotypy płci, ponieważ z konieczności, pod wpływem sytuacji wojennej stawały się nagle żywicielkami, aktywistkami i bojowniczkami ${ }^{38}$. Sprawczynie zapracowały na swoją widzialność w dyskursie

38 W tekstach dramatycznych autorstwa kobiet pojawiają się wprawdzie główne bohaterki doświadczające bezpośrednio wojny, jednak przypisane są one do strefy domowej (gospodyni, żona, matka), wytwórstwa (robotnica) lub sektora medycznego (pielęgniarka, sanitariuszka). Odstępstwem od tego modelu są zatem utwory, w których postaci kobiece odgrywają istotną rolę w funkcjonowaniu sił zbrojnych. Co ciekawe, opowiadają one o kobietach walczących na wojnach, które rozgrywały się w pierwszej połowie XX wieku, tak jak w przypadku dramatu chorwackiego duetu Jeleny Kovačić i Anicy Tomić Jagnie (Janje, 2014; o Šteficy Falicy) i utworu słoweńskiej autorki Simony Semenič My, europejskie trupy (Mi, evropski mrliči, 2015; o walczącej w oddziale partyzantów Milicy). 
medialnym, jednak w historii zapisały się także niechlubnie jako oprawczynie. Działania sadystycznych zbrodniarek wojennych, które odkryły w sobie poczucie misji - eliminowanie wrogów narodu ${ }^{39}$ - nie stanowią jak dotąd inspiracji dla autorek. Wzorca opisywanego kobiecego zwrotu ku działaniu i performatywności należy upatrywać raczej w próbie przełamywania ,traumy apatii”. Pojęcie to - autorstwa chorwackiej teatrolożki Natašy Govedić ${ }^{40}$ - zostało użyte do opisu twórczości Biljany Srbljanović i Ivany Sajko. Badaczka komentuje wyczulenie dramatopisarek na zjawisko wzrostu apatii, nie tylko wśród ofiar konfliktu, lecz także u niemych obserwatorów - świadków wojennego koszmaru. Podkreśla ona, że dla wielu ludzi podstawowym modusem egzystencji staje się zwyczajne biologiczne przetrwanie w sytuacji permanentnego lub cyklicznego zagrożenia. Wiąże się to niejednokrotnie z osadzeniem w obojętności względem nadużyć, co skrywa dużo głębszą traumę społeczną, ale też ją generuje. Jak zauważył amerykański psychiatra Robert Jay Lifton, osadzenie w traumie wiąże się z teatralnym procesem rozszczepiania lub zwielokrotniania ja: trauma radykalnie zmienia podmiot i bardzo często kreuje niezależne drugie ja, nową osobowośćc ${ }^{41}$. Bohaterki dramatów stają się zatem zdolne do odpierania ataków i mobilizacji, by włączyć się do walki przeciwko agresorowi.

Ze względu na innowacje dotyczące tematyki, ale też poetyki tekstu, za swoiste odkrycie w świecie dramatopisarstwa została uznana trylogia chorwackiej autorki Ivany Sajko (ur. 1975), na którą składają się utwory Archetyp: Medea - monolog dla kobiety, która czasami mówi (Arhetip: Medeja - monolog za ženu koja ponekad govori), Kobieta-bomba (Žena-bomba) i Europa - monolog dla matki Courage i jej dzieci (Europa - monolog za majku Courage i njezinu djecu) ${ }^{42}$. Ich podtytuły stanowią jednocześnie sugestie, by teksty traktować jak monodramy, choć trafniejszym określeniem wydaje się solo-performans lub kobiecy polilog. Zapisane w tekście hybrydyczne wypowiedzi mają wyraźny performatywny potencjał i stanowią podbudowę dla parateatralnych oraz koncertowych multiprojektów ${ }^{43}$. Interesujący jest osobiście praktykowany przez Sajko sposób scenicznej

39 „Rzeźniczki Bośni” oskarżone o zbrodnie wojenne to Biljana Plavšić, Albina Terzić, Rasema Handanović, Azra Alešević, Monika Simonović. Por. Zabilježene - Žene i javni život Bosne i Hercegovine u 20. vijeku. Drugo, dopunjeno i izmijenjeno izdanje, red. J. Čaušević, Sarajevo 2014, https://pl.scribd.com/doc/258137781/Zabiljezene-Zene-i-Javni-Zivot-Bosne-i-Hercegovine (dostęp: 7.11.2017) oraz M. Habarta, Kobiety zbrodniarki. Na przekór bałkańskiemu patriarchalizmowi i stereotypom ptci, ,Znaczenia” 2014, nr 10, http://www.e-znaczenia.pl/?p=1095 (dostęp: 8.01.2018).

40 N. Govedić, Trauma apatije: dvije dramatičarske postjugoslavenske Nigdine (Ivana Sajko i Biljana. Srbljanović) [w:] Dramski tekst danas u Bosni i Hercegovini, Hrvatskoj i Srbiji $i$ Crnoj Gori, red. S. Anđelković, Novi Sad 2004, s. 156.

41 R.J. Lifton [za:] C. Caruth, Trauma: Explorations in Memory, Baltimore 1995, s. 139.

42 I. Sajko, Žena-bomba, Zagreb 2004. Z całego tryptyku na język polski został przełożony jedynie dramat Kobieta-bomba: I. Sajko, Kobieta-bomba, tłum. D.J. Ćirlić, „Dialog” 2009, nr 9, s. 160-178.

43 Innowacyjną realizacją sceniczną było z pewnością czytanie koncertowe do partytury Rose is a rose is a rose is a rose (2008). Sajko, podążając za aktualnymi trendami, zaczerpnęła ze slamu poetyckiego technikę rytmicznego czytania, melorecytacji, żonglowania tekstem w takt ostrej muzyki granej na żywo. Artystka współpracuje z oryginalnym zespołem do zadań scenicznych, który tworzą: muzycy Nenad Sinkauz i Allen Sinkauz, dramaturg Sandro Siljan oraz artysta wideo Simon Bogojević Narach. Por. G. Abrasowicz, Od kobiety-bomby do kobiety-orkiestry. Twórczość Ivany 
realizacji tych utworów. Autorski zamysł performatywnego „czytania autoreferencyjnego" (autoreferencijalno čitanje) polega na tworzeniu kompilacji wybranych fragmentów kobiecych wypowiedzi zaczerpniętych z własnych postdramatycznych tekstów. Potwierdza to otwartość, łączliwość i dynamikę tekstu jako partytury kształtującej przestrzeń nieustannych interakcji, z której dobiega autentyczny, nieskrępowany głos autorki ${ }^{44}$.

Bohaterki w tryptyku Ivany Sajko - inkarnacje stanowiące odwołania do postaci z innych tekstów kultury (Medei, Europy, Matki Courage, seksbomby/terrorystki) - przedostają się do strefy wpływów i stają się pośredniczkami przemocy. Do (auto)destrukcyjnych czynów popycha je pragnienie zemsty za wyrządzone krzywdy, żądza władzy, obietnice poprawienia jakości życia własnego i bliskich, pożądanie lub potrzeba zrehabilitowania się w oczach otoczenia. Subwersywny tryptyk Sajko skłania do refleksji nad zmianą wektora związanego z funkcjonowaniem kobiety w grach społecznych ${ }^{45}$ : od uczestnictwa biernego ${ }^{46}$ do czynnego oraz od tożsamości życiodajnej do życie odbierającej ${ }^{47}$.

Na przejęcie inicjatywy decydują się w dramatach nie tylko wojowniczki, lecz także zwykłe skrzywdzone kobiety, dla których akty zemsty stanowią jednocześnie narzędzie ekspresji i sposób radzenia sobie ze stratą. Dramat Ivany Sajko Archetyp: Medea - monolog dla kobiety, która czasami mówi (2000) o zredukowanej zdarzeniowości został wprawdzie określony mianem monologu, jednak w jego ramach aktywizują się i przeplatają czasem trudne do zidentyfikowania głosy trzech kobiet: autorki, aktorki i bohaterki, co wzbogaciło oraz poszerzyło perspektywę artystycznej prezentacji. Odegrane przedstawienie ${ }^{48}$ jest jednocześnie równolegle realizowanym wykonaniem poza głównym tokiem dramatu - odtwarzalnym i prześladującym główną bohaterkę, która oddaje się refleksji na temat (nie)naruszalności szkieletu utworu Eurypidesa i w sposób polemiczny go aktualizuje.

Sajko ukazuje antyczną tragedię o dzieciobójczyni w kontekście obecnych przemian społecznych. Czynnikami usposabiającymi chorwacką Medeę do popełnienia zbrodni okazują się nie tylko chęć odwetu i rozładowania agresji na kochankach, lecz także wrogość do infantylnej polityki i toksycznej męskiej witalności reprezentowanej przez złotoustego karierowicza, współczesnej repliki Jazona. Zwielokrotniona bohaterka (Medea-autorka-aktorka, ale też suflerka) i jej wielogłos uzmysławiają, że role „kobiety” i ,matki” bywają skonfliktowane, co ostatecznie prowadzi do podważenia idei skromnego i ofiarnego macierzyństwa.

Sajko w kontekście zwrotu performatywnego [w:] Balkany performatywne. Rytuat - dramat - sztuka w przestrzeni publicznej, red. M. Sztandara, G. Injac, W. Kuligowski, Opole 2013, s. 135-146.

44 N. Tepavčević, Prikaz knjige „Prema ludilu (i revoluciji) - čitanje”, http://www.tkhgenerator. net/openedsource/ivana-sajko-prema-ludilu-i-revoluciji-citanje (dostęp: 8.1.2018).

45 Por. P. Bourdieu, Męska dominacja, thum. L. Kopciewicz, Warszawa 2004, s. 71. Autor wymienia ,typowo męskie” aktywności, takie jak przemoc, polityka, interesy, nauka.

46 Obecność kobiet sprowadzała się często wyłącznie do opieki nad członkami organizacji i zajmowania się funduszami.

47 L. Rafolt, Fiziološko-hormonalna opremljenost za terorizam i rađanje [w:] idem, Priučen na tumačenje - deset čitanja, Zagreb 2011, s. 193.

48 Nadtytuł dramatu brzmi: Notatki z odegranego spektaklu (Bilješke s odigrane predstave). 
Sajko uwydatnia możliwość odczytania postaci Medei jako prekursorki faktycznego zaprzeczania tradycyjnego podziału ról i dziedzictwa płci.

Niezwykle nośnym kontekstem interpretacyjnym w przypadku aktywizmu kobiet jest również kwestia terroryzmu. Ivana Sajko zdecydowała, że należy poświęcić uwagę kobiecemu pierwiastkowi zjawiska terroryzmu po 11 września 2001 roku i właśnie w aktywność terrorystki wpisuje takie pojęcia jak: władza, przemoc, technika, militaryzm, które są zazwyczaj silnie identyfikowane ze światem mężczyzn. Bohaterce technodramatu, bezimiennej Kobiecie-bombie (2003) została powierzona specjalna samobójcza misja likwidacji znanego polityka. Postać ta, którą można traktować jako odhumanizowaną, maksymalnie utylitarną maszynę, jest ucieleśnieniem koncepcji cyborga, wyrosłej na gruncie (post)gender studies ${ }^{49}$. Elementy układu wybuchowego scalają się ze skórą terrorystki, okalają jej zgrabne, atrakcyjne ciało (dodatkowa aktywacja metafory seksbomby), zamieniając je tym samym w organiczną tykającą bombę. Metafora ta zawiera w sobie bowiem pewne „re-wizje” kobiecości, a jednocześnie potencjał, który pozwala je przekroczyćc ${ }^{50}$.

Sajko zwraca uwagę na fakt, że kobiety są chętnie rekrutowane do organizacji terrorystycznych nie tylko ze względu na swoje posłuszeństwo, lecz także ze względu na aspekty fizjologiczne i fizyczne cechy dystynktywne ${ }^{51}$. Nowe kompetencje i (auto)destrukcyjna moc sprawcza bohaterki przyczyniają się jednak do rozsadzenia homogenicznych konceptów kobiecości ${ }^{52}$. Nie musi być ona percypowana wyłącznie w schemacie instynktownego macierzyństwa, który nie dopuszcza do uzewnętrzniania cech agresywnych, uchodzących za niekobiece ${ }^{53}$. Autorka podkreśla okoliczność istnienia fizjologiczno-hormonalnego uposażenia kobiet predestynującego je do rodzenia, pielęgnacji życia, ale też do zabijania ${ }^{54}$. Postdramatyczny manifest Sajko nakazuje zastanowić się nad możliwością realnego przełamania barier i anachronicznych paradygmatów związanych z płcią społeczno-kulturową ${ }^{55}$.

49 Por. D. Haraway, Manifest cyborgów: nauka, technologia i feminizm socjalistyczny lat osiemdziesiątych, tłum. S. Królak, E. Majewska, „Przegląd Filozoficzno-Literacki” 2003, nr 1, s. 49-87; L. Giresunlu, Cyborg Goddesses: The Mainframe Revisited, „At the Interface/Probing the Boundaries" 2009, Vol. 56, s. 157-187.

50 Szczegółowo, choć w nieco innym kontekście, pisałyśmy o tym dramacie Sajko w artykule: M. Koch, G. Abrasowicz, Ciało kobiece jako współczesna scena społecznego spektaklu. Tematy medyczne $w$ postjugosłowiańskim dramacie $i$ teatrze kobiecego autorstwa [w:] Medycyna w teatrze, red. M. Ganczar, K. Rutkowski, Warszawa 2017, s. 199-220.

51 Kobiety zamachowczynie do niedawna pozostawały zazwyczaj poza wszelkim podejrzeniem. W wielu krajach kobiet nie poddaje się szczegółowej kontroli osobistej. Kobieta może również łatwo zamaskować bombę, udając, że jest w ciąży.

52 Por. JM, Cyborg [w:] The Routledge Companion to Critical Theory, ed. S. Malpas, P. Wake, London-New York 2006, s. 166; S. Franklin, Cyborg, S. Kember, Cyborgfeminism [w:] Encyclopedia of Feminist Theories, ed. L. Code, London-New York 2006, s. 123-124.

53 L. Rafolt, Fiziološko..., s. 191.

54 Ibid., s. 193.

55 Problem uwikłania kobiet w sprawy terroryzmu podejmowany jest szerzej, także poza Bałkanami. Ważnym przykładem jest dramat autorstwa flamandzkiego pisarza Stefana Hertmansa Antygona w Molenbeek (Antigone in Molenbeek, 2017) o dylematach siostry terrorysty. Czytanie performatywne 
Również postać władczyni w utworze Ivany Sajko Europa-monolog dla matki Courage i jej dzieci (2004) ${ }^{56}$ wymyka się prostym klasyfikacjom. Tytułowa bohaterka pojawia się zarówno jako postać mitologiczna (naiwna kobieta uwiedziona i zgwałcona), jak i kontynent (topos Matki Ziemi) oraz formacja polityczna (Unia Europejska). Jednocześnie staje się ponowoczesną reinkarnacją matki Courage Bertolta Brechta, ponadto jako wyobrażenie towarzyszki życia zdobywcy-imperatora, a także wcielenie archetypu gniewnej Wielkiej Matki. Europa obserwująca zbrojne posunięcia dużo starszego Pułkownika (symbolu władzy militarnej), choć jest zasypywana łupami wojennymi, zaczyna odczuwać niedosyt i rozczarowanie. Nieobecny i jałowy mąż (uosabiający u Sajko biologiczny kryzys męskości) nie jest w stanie spłodzić syna następcy, kobieta odczuwa jednak niezbywalną potrzebę przekazania życiowej energii i odrodzenia się w nowej odsłonie jako opiekunka i obrończyni. Bohaterka staje się matką w sensie symbolicznym. Wychodzi poza sferę domową i zaczyna pełnić służbę polityczną oraz sprawować opiekę nad swoimi dziećmi - kilkumilionową rozśpiewaną armią sierot, którą ofiarował jej Pułkownik. Europa uosabia państwowość w formie matczyzny (która stanowi wyższe stadium ojczyzny). To matka wymagająca, która dostrzega realne zagrożenia, ale nie rezygnuje z ponoszenia ofiar oraz zaprzestania walk. Snuje plany o bezpiecznej strefie, w której mogłaby zgromadzić wokół siebie i zjednoczyć swoje dzieci.

Mimo ewidentnych odwołań do konkretnej rzeczywistości politycznej analizowany tekst dramatyczny przedstawiający kręte drogi ginokracji ${ }^{57}$ ma wymiar uniwersalny. Kreacja Nadmatki zawiera w sobie wyobrażenia o współczesnych supermatkach, które zmuszane są do transformacji w ,supermenki”, ale coraz częściej odmawiają umacniania ciągu repetycji społeczno-kulturowych zadań.

tej sztuki odbyło się podczas Festiwalu MALTA w Poznaniu (wykonanie: Małgorzata Gorol, reżyseria: Anna Smolar, przekład na język polski Jerzy Koch). Na uwagę zasługuje także tekst napisany przez niemieckiego dramaturga Torstena Buchsteinera. NordOst (2005) przedstawia relacje trzech kobiet, które doświadczyły, każda na swój sposób, ataku na moskiewski teatr na Dubrowce w 2002 roku. Na podstawie dramatu zrealizowano spektakle w wielu europejskich teatrach, ale też w USA. Utwór wzbudził również zainteresowanie serbskiej reżyserki Jany Maričić (Severoistok, Teatr Bitef, 2018).

56 Dramat ten został poddany pogłębionej analizie w artykule: M. Koch, G. Abrasowicz, Re-wizje Europy we wspótczesnym dramacie chorwackim (,Europa - monolog dla Matki Courage i jej dzieci” Ivany Sajko), „Miscellanea Posttotalitariana Wratislaviensia”, t. 2: Postkolonializm - tożsamość gender. Europa Środkowa, Wschodnia i Poludniowo-Wschodnia, red. A. Matusiak, Wrocław 2014, s. 249-266.

57 Por. K. Podlaszewska, Anioł czy Hetera. Demistyfikacja kobiecej natury i nadchodzaca ginokracja, „Odra” 2004, nr 11, s. 17. 


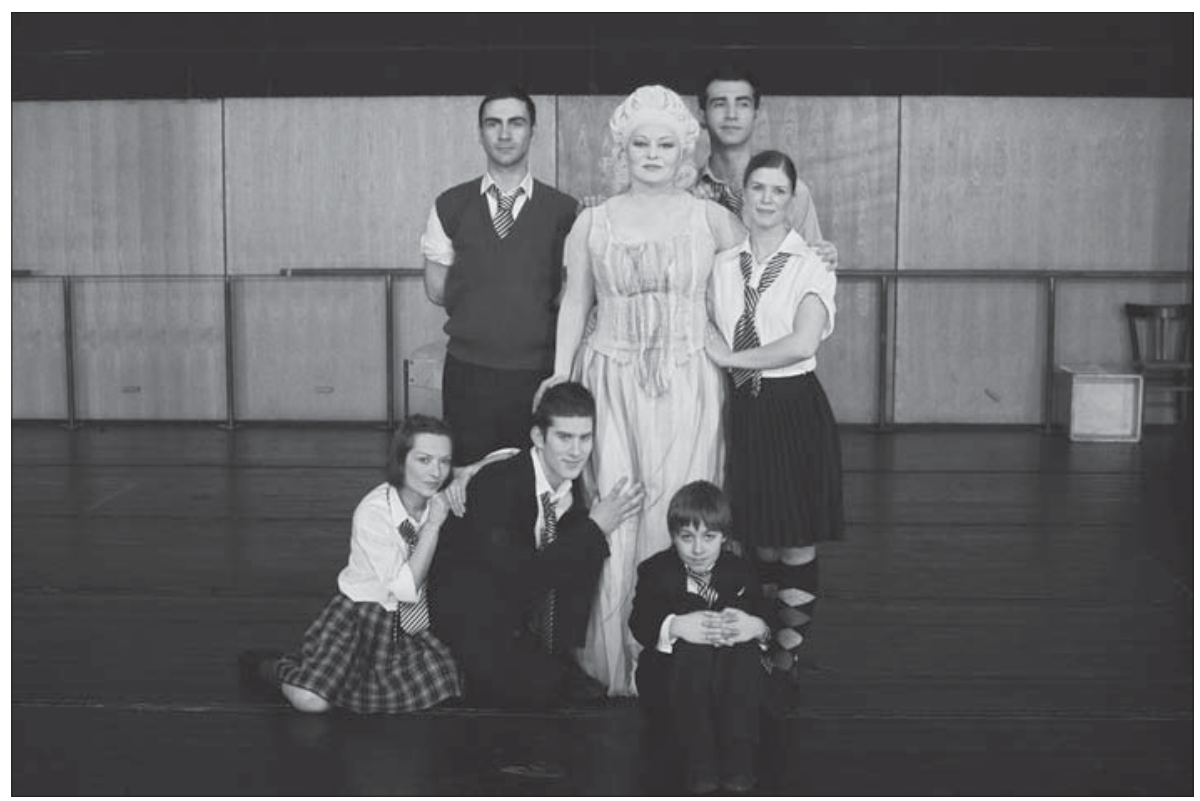

Fot. 3. I. Sajko, Medeja/Žena-bomba/Europa, reż. I. Sajko, D. Ruždjak-Podolski, F. Perković-Gamulin, ZeKaeM, Zagreb 2007.

\section{Wnioski}

Podsumowując, należy podkreślić, że od lat dziewięćdziesiątych XX wieku dramat i teatr (post)jugosłowiański kobiecego autorstwa stał się niezwykle ważnym elementem dyskursu o wojnie, przemocy i uchodźcach. Autorki w swoich sztukach starały się przedefiniować pojęcie konfliktu, koncentrując się na przemocy wobec kobiet oraz - co stanowi novum - przemocy ze strony kobiet. Zauważyć można ciekawie zarysowaną perspektywę genderową, w wielu przypadkach także feministyczną. Kobiece narracje uzupełniają oficjalne obrazy wojny i wzbogacają spojrzenie na konflikt, autorki podejmują bowiem tematy ignorowane, wstydliwe, niewygodne, często tabuizowane. Dramaty te, nasycone różnorodnym i zniuansowanym podejściem do tematu wojny, ukazują wielowymiarowość kobiecych ról społecznych - od oczywistej roli ofiar gwałtów etnicznych i przemocy w rodzinie poprzez rolę wyobcowanych (uchodźczyń, wycofanych, oczekujących na powrót zaginionych) po wcale nieoczywiste sprawstwo i uczestnictwo kobiet w aktach przemocy (tym samym burzą stereotyp, że kobiety są głównie ofiarami, a nie sprawczyniami zbrodni i przemocy).

Kolejny wniosek, jaki się nasuwa, to trajektorie oddziaływania dramatu $i$ teatru. Obserwujemy wyraźne przejście od biernego wysłuchania/przeczytania historii (oralność, dokumentalizm) ku aktywności polegającej na destylowaniu realnych historii $\mathrm{w}$ formie sztuki zaangażowanej (artywizm). Istotnym aspektem 
jest też moc emisyjna (post)jugosłowiańskiego dramatu i teatru, polegająca na pokonaniu drogi od lokalnego/regionalnego zdarzenia oraz doraźności (publicystycznej czy interwencji psychoterapeutycznej) do uniwersalizującego uogólnienia. Ważną cechą dramatu i teatru jest uchwycenie paradygmatu przemocy bez względu na sztafaż geopolityczny oraz obnażenie mechanizmu, który - jak się okazało - przystaje obecnie do innych sytuacji konfliktów (np. wojny w Syrii, sytuacji w Iranie czy Afganistanie, bo tam sztuki omawianych autorek są ostatnio realizowane).

W tym kontekście jeszcze jedno wydaje się ważne. Oprócz kwestii dawania świadectwa fundamentalna stała się także funkcja terapeutyczna i katartyczna dramatu/teatru, co stanowi o jego sile. W tym sensie dramat i teatr (post)jugosłowiański okazały się swoistym laboratorium dla innych kultur w kwestii wypracowywania języków artystycznych i formy w przetwarzaniu współczesnych traum wojennych. Wojna w Jugosławii bywała też często inspiracją dla innych kultur. Brytyjska autorka Sarah Kane nie kryła, że impulsem do powstania jej debiutanckiego dramatu Blasted (Zbombardowani) z 1993 roku były wydarzenia wojenne z Bośni i Hercegowiny. Inspirowały się nimi również dramatopisarki między innymi z USA (Eve Ensler, Konieczne cele [Necessary Targets]; Catherine Filloux, Dom Lemkina [Lemkin's House], Pies i wilk [Dog and Wolf]) i Kanady (Colleen Wagner, Pomnik [The Monument]). Pod względem poszukiwania formy i języka do wyartykułowania tematów związanych z przemocą wojenną i uchodźctwem dramat (post)jugosłowiański mimo woli znalazł się w awangardzie, by nie powiedzieć w eksperckiej grupie poszukującej adekwatnych środków w tzw. kobiecym dramacie (anty)wojennym, choć paradoksalnie - mimo niewątpliwych osiągnięć tematyczno-formalnych - ten przywilej bycia w awangardzie nie do końca cieszy, jeśli wziąć pod uwagę trudny temat, brzemienny w znaczenia oraz artykułowane sensy.

\section{Bibliografia}

Abrasowicz G., Dramat ciała, ciało w dramacie. Twórczość serbskich i chorwackich dramatopisarek w latach 1990-2010, Wrocław 2016.

Abrasowicz G., Od kobiety-bomby do kobiety-orkiestry. Twórczość Ivany Sajko w kontekście zwrotu performatywnego [w:] Bałkany performatywne. Rytuat-dramat-sztuka w przestrzeni publicznej, red. M. Sztandara, G. Injac, W. Kuligowski, Opole 2013.

Arsenijević D., Odrodzić płeć kości: polityka pamięci w Bośni i Hercegowinie, thum. M. Koch, K. Taczyńska, „Teksty Drugie” 2017, nr 2.

Basha D., Prst, prev. Q. Ondozi [w:] Zbirka savremene drame, ur. V. Bošković, Beograd 2012.

Bourdieu P., Męska dominacja, tłum. L. Kopciewicz, Warszawa 2004.

Čale Feldman L., Postoji li suvremeno hrvatsko dramsko žensko pismo?, „Republika” 1996, br. 3-4.

Caruth C., Trauma: Explorations in Memory, Baltimore 1995. 
Giresunlu L., Cyborg Goddesses: The Mainframe Revisited, „At the Interface/Probing the Boundaries" 2009, Vol. 56.

Goris Y., Hollander S., Activism, Artivism and Beyond. Inspiring Initiatives of Civic Power, Partos 2017, https://www.partos.nl/fileadmin/files/Documents/Activism Artivism_and_Beyond.pdf(dostęp: 8.01.2018).

Govedić N., Trauma apatije: dvije dramatičarske postjugoslavenske Nigdine (Ivana Sajko i Biljana. Srbljanović) [w:] Dramski tekst danas u Bosni i Hercegovini, Hrvatskoj i Srbiji i Crnoj Gori, ur. S. Anđelković, Novi Sad 2004.

Habarta M., Kobiety zbrodniarki. Na przekór batkańskiemu patriarchalizmowi i stereotypom ptci, ,Znaczenia” 2014, nr 10, http://www.e-znaczenia.pl/?p=1095 (dostęp: 8.01.2018).

Haraway D., Manifest cyborgów: nauka, technologia i feminizm socjalistyczny lat osiemdziesiatych, tłum. S. Królak, E. Majewska, „Przegląd Filozoficzno-Literacki" 2003, nr 1.

JM, Cyborg [w:] The Routledge Companion to Critical Theory, ed. S. Malpas, P. Wake, London-New York 2006.

Kazaz E., Krvavi lom društva i poetički prevrati romana, „Sarajevske Sveske” 2006, br. 13, http://sveske.ba/en/content/krvavi-lom-drustva-i-poeticki-prevrati-romana (dostęp: 8.01.2018).

Kazaz E., Prizori uhodanog užasa, „Sarajevske Sveske” 2004, br. 5, http://www.sveske.ba/bs/content/prizori-uhodanog-uzasa (dostęp: 8.01.2018).

Koch M., Abrasowicz G., Ciało kobiece jako współczesna scena społecznego spektaklu. Tematy medyczne w postjugosłowiańskim dramacie i teatrze kobiecego autorstwa [w:] Medycyna w teatrze, red. M. Ganczar, K. Rutkowski, Warszawa 2017.

Koch M., Abrasowicz G., Re-wizje Europy we współczesnym dramacie chorwackim (,Europa - monolog dla Matki Courage i jej dzieci” Ivany Sajko), „Miscellanea Posttotalitariana Wratislaviensia", t. 2: Postkolonializm-tożsamość-gender. Europa Środkowa, Wschodnia i Południowo-Wschodnia, red. A. Matusiak, Wrocław 2014.

Lukić D., Ženski pogled na mušku stvar. Ratna tematika u suvremenih hrvatskih dramatičarki s jednom muškom iznimkom [w:] Govor drame. Govor glume. Zbornik radova sa simpozijuma „Dramski tekst danas u Bosni i Hercegovini, Hrvatskoj i Srbiji i Crnoj Gori”, ur. S. Anđelković, B. Senker, Zagreb 2007.

Nahoum-Grappe V., Gwatt jako broń wojenna, tłum. K. Bartkiewicz [w:] Czarna księga kobiet, red. C. Ockrent, S. Treiner, thum. K. Bartkiewicz i in., Warszawa 2007.

Nikčević S., Kako prikazati ljudske rane na sceni. Ratne teme u hrvatskoj, bosanskoj $i$ angloameričkoj drami, Zagreb 2016.

Nikčević S., Lydia Scheuermann Hodak ili dramski pisac izvan trendova [w:] L. Scheuermann Hodak, Žene, ljubav i ratovi, Osijek 2009.

Podlaszewska K., Anioł czy Hetera. Demistyfikacja kobiecej natury i nadchodzaca ginokracja, „Odra” 2004, nr 11.

Poljak-Rehlicki J., Ključ za preživljavanje: ženska ratna trauma u monodrami „, Slike Marijine” [w:] Size zero/mala mjera 2. Ženski lik u književnom tekstu, ur. A. Nikčević-Batrićević, Podgorica 2011.

Rafolt L., Priučen na tumačenje - deset čitanja, Zagreb 2011.

Rafolt L., Uvod [w:] Odbrojavanje: antologija suvremene hrvatske drame, ur. L. Rafolt, Zagreb 2007. 
Franklin S., Cyborg, Kember S., Cyborg feminism [w:] Encyclopedia of Feminist Theories, ed. L. Code, London-New York 2006.

Sablić-Tomić H., Gola u snu. O ženskom književnom identitetu, Zagreb 2005.

Sajko I., Žena-bomba, Zagreb 2004.

Scheuermann Hodak L., Slike Marijine [w:] eadem, Žene, ljubav i ratovi, Osijek 2009. Shalhoub-Kevorkian N., Liberating Voices: The Political Implications of Palestinian Mothers Narrating Their Loss, „Women Studies International Forum” 2003, Vol. 26, Issue 5.

Tepavčević N., Prikaz knjige „Prema ludilu (i revoluciji) - čitanje”, http://www. tkhgenerator.net/openedsource/ivana-sajko-prema-ludilu-i-revoluciji-citanje (dostęp: 8.01.2018).

Yuval-Davis N., Nacionalistički projekti i rodni odnosi, „Treća” 2003, br. 1-2 (V).

Zabilježene - Žene i javni život Bosne i Hercegovine u 20. vijeku. Drugo, dopunjeno i izmijenjeno izdanje, ur. J. Čaušević, Sarajevo 2014, https://pl.scribd.com/ doc/258137781/Zabiljezene-Zene-i-Javni-Zivot-Bosne-i-Hercegovine (dostęp: 7.11.2017).

Zërat, Voices, Glasovi, ur. J. Neziraj, A. Zadel, Priština 2006.

Zlatar A., Tekst, tijelo, trauma: ogledi o suvremenoj ženskoj književnosti, Zagreb 2004. 